\title{
QUEEN'S
UNIVERSITY
BELFAST
}

\section{The evolution of public-private partnership in Ireland: a sustainable pathway?}

Sheppard, G., \& Beck, M. (2016). The evolution of public-private partnership in Ireland: a sustainable pathway? International Review of Administrative Sciences. https://doi.org/10.1177/0020852316641494

\section{Published in:}

International Review of Administrative Sciences

\section{Document Version:}

Peer reviewed version

Queen's University Belfast - Research Portal:

Link to publication record in Queen's University Belfast Research Portal

\section{Publisher rights}

(C) 2016 The Authors

\section{General rights}

Copyright for the publications made accessible via the Queen's University Belfast Research Portal is retained by the author(s) and / or other copyright owners and it is a condition of accessing these publications that users recognise and abide by the legal requirements associated with these rights.

Take down policy

The Research Portal is Queen's institutional repository that provides access to Queen's research output. Every effort has been made to ensure that content in the Research Portal does not infringe any person's rights, or applicable UK laws. If you discover content in the Research Portal that you believe breaches copyright or violates any law, please contact openaccess@qub.ac.uk. 
The Evolution of Public Private Partnership in Ireland: A Sustainable Pathway?

Gail Sheppard $^{1}$ and Matthias Beck ${ }^{2}$

1 corresponding author Gail Sheppard, Lecturer in Accounting, IT Tallaght, PhD student, Queen's University Belfast.

Address: Dept. Accountancy and Professional Studies, IT Tallaght, Belgard Road, Dublin 24, Ireland Email: gail.sheppard@ittdublin.ie

Telephone: 0035314042178

2 Matthias Beck, Chair in Public Sector Management, Queen's University Belfast. Management School Riddel Hall 185 Stranmillis Road Belfast BT9 5EE BT9 5EE United Kingdom

m.beck@qub.ac.uk

Bio

Gail Sheppard, ACMA, M.Sc. is a part-time PhD student researching Public Private Partnership (PPP) in the Queen's University Management School, in Belfast. Her study examines the rationale for the adoption of PPP in Ireland and the extent of the influence of policy transfer and institutional isomorphism in its adoption and in achieving the aims set out by government. As a lecturer in Management Accounting at the Institute of Technology, Tallaght, in Dublin her ongoing research interests include value for money in, and performance measurement of, public resource allocation. Prior to this she has held posts as a Management Accountant in industry.

Professor Matthias Beck, PhD (MIT) MArch MUP (Kansas) FRSA is chair in Public Sector Management at the Queen's University Management School in Belfast. His main research interests are in the areas of Risk, State-Business relationships, and the Political Economy of Management more generally. Matthias completed a study into the role and effectiveness of public-private partnerships (LIFT) in the development of enhanced primary care premises and services for the UK National Health Service's (NHS) Service Delivery and Organisation programme in 2010. 


\section{Abstract}

Ireland is a latecomer to Public Private Partnership (PPP) having only adopted it in 1998. Prior to the credit crisis, Ireland followed the UK model with PPPs being implemented in transport, education, housing/urban regeneration and water/wastewater. Having stalled during the credit crisis, PPP has been reactivated recently with the domestic infrastructure stimulus programmei. The focus of this paper is on Ireland as a younger participant in PPP and the nexus between adoption patterns and sustainability characteristics of Irish PPP. Using document analysis and exploratory interviews, the paper examines the reasons for Ireland's interest in PPP which cannot be attributed to economic rationales alone. We consider three explanations: voluntary adoption - where the UK model was closely followed as part of a domestic modernisation agenda; coercive adoption - where PPP policy was forced upon public sector organisations; and institutional isomorphism - where institutional creation and change around PPP was promoted to help public sector organisations gain institutional legitimacy. We find evidence of all three patterns with coercive adoption becoming more relevant in recent years, which is likely to affect sustainability adversely unless incentives for voluntary adoption are strengthened and institutional capacity building is boosted.

\section{Points for Practitioners}

There are many reasons public sector organisations procure via PPP and motivations can change over time. In Ireland PPP adoption changed from being largely voluntary to increasingly coercive. Irrespective of motives, PPP procurement must be underpinned by incentives and institutional enabling mechanisms which should be strengthened to make Ireland's PPP strategy sustainable. 


\section{Key Words}

commercial sensitivity, isomorphism, new public management, policy transfer, public private partnership, transparency.

\section{Introduction}

The extensive use of PPPs in Europe has been identified as contributing to fiscal instability (Budina et al., 2007; Corbacho et al., 2008). Typically, it is assumed that government decisions to introduce PPPs have been based on a need to develop infrastructure in the absence of adequate fiscal resources. Using the example of Ireland, this paper suggests that the decision to implement PPPs can follow other than economic or pragmatic rationales.

Ireland can be considered a late adopter of PPP, and this relates to its moderate uptake of New Public Management (NPM) more generally, with it being classified as middles intensity adopter. Although the link between PPP / PFI and NPM is not absolute, with some research identifying it as 'defining characteristics of third way governments' (Hodge, 2004), PPP procurement mechanisms lend themselves to NPM concepts such as 're-engineering' and 'modernisation' (Massey, 2010) in that it draws on private sector practices in public service delivery (Broadbent et al., 2004; Broadbent et al., 2005. By mid-2009, Ireland had only six PPP projects in operation (Reeves, 2013b), representing less than $0.5 \%$ of all EU PPP contracts signed from 1990 to 2009. Although a late PPP adopter, Ireland is a 'rapid follower' of the UK model and increasingly a leading practitioner in transport, education, housing/urban regeneration and water/wastewater (Northoff, 2008). This is striking since, as a wealthy late adopter, Ireland had alternative options. Rather than implementing PPP via application of the UK model, it could have modified PPP policy to maximise responsiveness to local needs and preferences. This paper discusses Ireland's decision to follow the UK model and the implications in terms of policy transfer, institutional developments and sustainability.

Specifically we: define PPP; examine the background to the approach adopted in Ireland; outline the theoretical framework and discuss how policy transfer theory and institutional theory is 
used to frame this research; discuss our methodology; apply the theoretical framework to our document analysis and exploratory interviews; discuss findings; and set out the conclusions.

\section{Defining Public Private Partnership}

PPPs can be described as 'competitive business ventures' between the public and private sectors (Teicher et al., 2006) and providing 'private finance initiatives' for infrastructure projects (Leinhard, 2006). There is no single definition of PPP. The UK views PPP as procurement approach that brings public and private sectors together in long-term partnerships for mutual benefit (Akintoye et al., 2003). The Irish government defines PPP as a public services/infrastructure procurement method that emphasises value for money and delivering quality public services. ${ }^{\text {ii }}$ Two general PPP arrangements can be identified. One emphasises the use of private finance and the other is service delivery by the public sector (Abdel Aziz, 2007). Both types of are used in Ireland. More recent definitions describe PPP as a 'a set of governance tools as well as a set of language games' with both having 'long historical pedigrees' (Hodge and Greve, 2009), which encompass at least five families of governance arrangements, including long-term infrastructure contract-type PPPs (Hodge and Greve, 2010). Although this strand of PPP covers several arrangements, it typically specifies outputs based on long-term contracts (Hodge and Greve, 2010). Our analysis focuses on this type of PPP, which, following the UK Private Finance Initiative (PFI) model, is largely privately funded (Hodge and Greve, 2010). 


\section{Background}

There is a history of private sector involvement in service and infrastructure delivery in Ireland. Religious institutions have run schools and hospitals (Connolly et al., 2009b) and in the 1980s and 1990s, toll bridges in Dublin were built with private sector involvement and refuse collection privatised (Reeves, 2003).

PPPs were formally introduced following the Report to the Inter-Departmental Group in Relation to Public Private Partnerships (Farrell Grant Sparks, 1998). There was little justification of why the Irish government should adopt these policies (Hearne, 2009). The motivation appears to have been filling the so-called infrastructure gap which arose from curtailment of capital spending in the 1980s and early 1990s (NESC, 1999). Subsequently investment relied heavily on EU fiscal transfers (Reeves, 2003). Between 1993 and 2000, European transfers became less important as economic growth made Ireland the fastest growing OECD economy by 2000 (Reeves, 2003).

The Maastricht Treaty convergence criteria meant Irish budget deficits could not exceed 3\% nor the gross government debt to GDP ratio exceed 60\%. Ireland's budget deficit never went above $3 \%$ during the 1990s and the ratio of gross government debt fell below 60\% in 1998 until 2008. There was no pressing need to finance infrastructure through PPP, so why did a fiscally healthy Ireland engage in PPP?

The National Economic and Social Council stated that PPPs brought efficiency gains to the public sector (NESC, 1999). PPP was not the only vehicle through which such benefits could be acquired. Hodge et al. (2007) correctly suggest that PPPs enjoyed popularity among governments eager to please markets and unwilling to raise tax rates. Additional explanations for the adoption of PPPs arise from the literature on policy transfer and institutional isomorphism.

\section{Theoretical Framework: Policy Transfer Theory and Institutional Theory}

The study of policy transfer draws on policy diffusion studies, a sub-set of comparative politics literature (Dolowitz et al, 1996; Evans, 2009). Policy transfer can be defined as 'a process in which 
knowledge about policies, administrative arrangements, institutions etc in one time and/or place is used ... in another time and/or place' (Dolowitz et al., 1996). Policy transfer causes organisations to mimic others (Dolowitz et al., 1996). It can increase the effectiveness of government operations (Marsh et al., 2009) and help legitimise organisations (Connolly et al., 2009a). Early transfer studies relate to voluntary transfer which can occur due to dissatisfaction with the status quo. More recent studies explore direct coercive transfer which occurs when supra-national institutions, such as the IMF, force the adoption of a policy; together with indirect coercive transfer which arises when interdependence related externalities force governments to collaborate (Dolowitz et al., 1996). Some studies of change involving the diffusion of institutional elements utilise policy transfer and institutional isomorphism as cognate terms (Marsh et al., 2009). There is a rationale for combining policy transfer and institutional theories (Radaelli, 2000) and we take this approach. Governments operate in an institutional environment which influences their actions (Matos-Castaño et al., 2014) and institutional theory can explain why governmental organisations often mimic each other (Connolly et al., 2009a). Institutional theories assume that to gain organisational legitimacy and secure access to resource organisations must meet expectations by external and internal stakeholders (Brignall, et al. 2000). Organisational structure, policies and procedures relate to expectations and 'myth' about what is socially and economically acceptable, which are rationalised and gain legitimacy (DiMaggio et al., 1983; Brignall et al., 2000).

DiMaggio and Powell (1983) describe three types of institutional isomorphism - coercive, mimetic and normative. Connolly et al. (2009a) suggest PPPs were introduced in the UK as otherwise a project would not be implemented (Newberry, 2004). The manner in which PPPs were introduced into Ireland is said to have involved 'mimicry' (Connolly et al. 2009a). Research on PPP policy in British Columbia (Canada), Victoria (Australia) and South Africa shows that the original model was modified beyond the isomorphic 'one size fits all' approach by diffusion carriers such as relational networks, local advocates and consultants (Jooste et al., 2011). 
Research into the institutional impacts on the implementation of PPP explores successful institutional environments as contexts where governments understand the complexity arising within PPPs (Willems et al., 2011). PPPs require a variety of new types of institutional capacity (Jooste et al., 2009) and institutional shortcomings can lead to performance problems (Matos-Castano et al., 2014). The first generation of PPPs in the Netherlands in the early 1990s suffered from financial and structural problems. The second generation of PPPs came about after the government assessed international experiences of PPP (Matos-Castano et al., 2014).

This study draws on elements of the Dolowitz and Marsh framework (2000) which asks how the process of policy transfer relates to policy success or failure. Hodge and Greve (2011) also investigate how success of PPP can be assessed and note that broad multifaceted definitions of PPP success could relate to any of the dimensions of PPP including project, organisation, policy symbol and context and culture (see also Hodge 2010). This implies the assessment of PPP requires theoretical frameworks which take into account the nature of PPP as a developmental and emerging phenomenon rather than looking at economic outcomes only (Hodge and Greve, 2011).

A number of frameworks allow for a process-based assessment of PPPs. Verhoest et al. (2013) suggest that the emergence of 'PPP policies, regulations and supporting institutions, as well as ... differences ...' can be understood by reference to 'specific macro-institutional variables like culture, legal tradition, polity, economic-financial evolutions and actor constellations' while 'we might study policy diffusions and transfer processes to understand the spread of PPP propagating policies, regulations and supporting institutions'. Verhoest et al (2013) suggest a framework of eight variables for the dimension of political commitment to PPP, including aspects of the PPP policy framework, previous PPP experience, political stability, effects of the financial crisis, policy changes due to crisis, legal changes, scope of PPP law and elements of the legal framework.

While this framework is specifically aimed at assessing, as predictor of success, political commitment to PPP, we focus on the sustainability of the Irish PPP programme in its current form. This delimitation is based partly on acknowledged difficulties in defining and assessing PPP success 
(Hodge and Greve, 2011) and on the fact the Irish PPP programme is ongoing with increased postcrisis government support, which gives paramount importance to questions of institutional sustainability and socio-political legitimacy. To examine the sustainability of the Irish PPP programme we borrow from Jooste, Levitt and Scott's (2009) framework which groups 19 PPP success factors under the three main headings: building capacity, obtaining legitimacy and balancing interests (Jooste et al., 2009). We apply nine measures from this approach to our analysis.ii While our analysis does not focus on explicit hypothesis testing, we approach our analysis through a novel combination of the Jooste, Levitt and Scott (2009) framework with the predictions by Dolowitz and March (2000). Based on these sources, we expect that the most sustainable PPP environment is associated with (2), voluntary policy transfer with strong institutional capacity building, where institutional environments and institutional capacity are changed and developed to meet the challenges arising from PPP procurement [see Table 1]. This is followed by (4), coercive policy transfer and strong institutional capacity building; (1), voluntary policy transfer and weak institutional capacity building; and (3), coercive policy transfer and weak institutional capacity building. The results section examines these aspects in the Irish context.

Table 1: Factors affecting the sustainability of PPP policy transfer INSERT FIGURE

\section{Methodology}

The research takes a predominantly deductive approach in which the predictions of our combined framework are contrasted with concrete experiences of recent Irish PPP developments. We draw on exploratory interviews with a senior member of the parliamentary public accounts committee, a senior trade union official and a senior economist working on PPP project financing in an investment bank. A document analysis explores rationales relating to PPP policy-making. We examine how 
patterns of PPP adoption, together with aspects of institutional capacity building is affecting the sustainability of this programme. Our aim is to provide suggestions for improving the sustainability of this PPP programme to avoid the rapid policy shifts observed in other venues such as the UK.

\section{Results}

\section{Evidence of Policy Transfer}

Ireland's role as a late adopter of UK style PPP is exemplified by policy guidelines (Sheppard, 2015). Irish guidelines produced to assist those engaged on PPP projects within the local government sector (Department of the Environment, 2003) closely mirror the UK Green Book (HM Treasury, 2003). This concerns PPP project implementation; training for the public and private sectors; availability of expertise through a procurement unit; allocation of risk between the parties; and the composition of the public sector comparator.

Our exploratory interviews suggest that policy transfer was both voluntary and coercive to some degree. A senior member of the public accounts committee noted in an interview with the authors that the choice to follow closely elements of the UK model was based on pragmatic considerations and as such voluntary. This informant suggested, however, that assumptions borrowed from the UK were inaccurate and that the approach also raised issues of transparency. Noting this lack of transparency related to industry expectations of commercial confidentiality, the informant said this could be addressed by publishing outcome related cost figures only. This suggests that while the decision to adopt UK-style PPP was largely voluntary, industry expectations created a coercive element with regard to the evaluation of the scheme.

Our senior trade union informant maintained that for local authorities the adoption of PPP was largely coercive. He cited examples of water projects where direct public procurement would have been cheaper and deduced that the Department of the Environment was biased in favour of PPP. He felt commercial confidentiality was unjustifiably forced on the public by industry, since 
'information is only commercially sensitive at the bidding stage, while post contract, the use of public money should mandate public disclosure.'

Meanwhile our senior economist and bank representative involved in PPP project finance, highlighted that the initial adoption of PPPs had been largely voluntary and was difficult to explain on pragmatic or economic grounds, indicating potentially symbolic or legitimatory drivers. Current PPP adoption reflects the public sector's restricted access to borrowing. This confirms the view that PPP adoption shifted from voluntary to coercive policy transfer.

\section{Evidence of Institutional Capacity Building}

Applying the Jooste, Levitt and Scott Framework (2009) to document analysis and initial exploratory interviews, this section focuses on institutional structures created by Ireland to support PPP procurement. The analysis focuses on nine measures: supportive legal framework, political commitment, buy-in from key constituents, good public sector knowledge of PPPs, a PPP unit, measures to coordinate deal flow, program transparency, and ensuring the quality of projects while implementing independent oversight.

(1) Developing and applying a supportive legal framework

In 2001 and 2002 Ireland passed acts to facilitate state participation in PPPs: the Transport (Railway Infrastructure) Act 2001; the State Authorities (Public Private Partnership Arrangements) Act 2002; and the National Development Finance Agency Act 2002. The last established the National Development Finance Agency (NDFA) which funds infrastructure through long-term debt and equity. The role of the NDFA was expanded through amending legislation which tasked it with establishing a Centre of Expertise for procuring PPP projects on behalf of State authorities. The NDFA was further authorised to provide contract management services for PPPs projects. Accordingly, a consistent legal framework appears to be in place to support the implementation of PPP. 


\section{(2) Providing political commitment}

PPP was endorsed by the 1997 - 2002 government and PPP pilot projects were announced in 1999 (Connolly et al., 2009b). The National Development Plan 2000 - 2006 (NDP) confirmed the government's commitment to PPP by highlighting its potential in transport and environmental projects. This was abandoned with the economic crisis which put 24 projects on hold (Reeves, 2013b). Following recommendations by the Irish Business and Employers Confederation (IBEC), the Minster for Public Expenditure and Reform announced a $€ 2.25$ billion domestic infrastructure stimulus programme in 2012. ${ }^{\text {iv }}$ Details were announced in 2013 regarding Phase 1 to be delivered through PPP, valued at $€ 1.4$ billion. The government also agreed $€ 250$ million in new PPP projects in the areas of schools, energy efficiency and roads.

One motivation for this PPP programme was to create jobs and stimulate the economy. Moreover, the NDFA explained that it was using the PPP programme to keep borrowing 'off balance sheet' (NDFA, 2013). This indicates that the relevance of PPP to Irish politics had changed significantly with PPP no longer being a voluntary option and becoming a necessity in terms of maintaining adequate public investment. It also implies that political commitment has increased considerably from a stage where PPP was considered a fashionable approach to procurement which created an image of modernisation in line with UK policy, to one where PPP became the main (if not sole) option in dealing with capital spending shortfalls.

This view was confirmed by the senior economist who suggested that the PPP scene today was characterised by strong political commitment at all government levels as this was now seen as a tool for overcoming funding shortfalls.

\section{(3) Gaining buy-in from key constituents}

Buy-in from key constituents can be illustrated by a number of key submissions and reports supporting PPPs by organisations such as the Irish employers' association (IBEC), the construction 
industry, advisory groups and, initially, trade unions and community groups. In January 1998, IBEC and the Construction Industry Federation (CIF) presented a report to government which argued for PPPs as a means of addressing the infrastructure deficit. The social partnership agreement, Programme for Prosperity and Fairness (Department of the Taoiseach, 2000) stated that PPP would contribute significantly to the implementation of the NDP, drawing on the experience gained from then current PPP pilot projects. Mechanisms would be agreed by the relevant social partners to deliver efficient, transparent and fair contracts, tendering and contractual procedures for PPP procurement.

In November 2001 a 'Framework for Public Private Partnerships' (Public Private Partnership Advisory Group, 2001) was launched involving an advisory group comprising representatives of IBEC, trade unions, the CIF and the main PPP agencies. The report recognised the critical role of social partnership and stakeholder consultation and initially trade unions favoured PPP. The unions interpreted the guidelines on PPP consultation as requiring detailed consultations on Procurement Assessment Reports (PAR), which consider different procurement alternatives in terms of economic, engineering and organisational aspects. ${ }^{\vee}$ In the case of a replacement wastewater treatment plant, five roundtable meetings took place where stakeholders raised questions and made changes to the PAR, prior to its 2007 submission to the Department of the Environment (Reeves, 2013a).

In the case of another PAR of mid-2006, consultation was less cooperative and failed to facilitate agreement. In the case of a mixed tenure housing and urban regeneration PPP proposed as a design, build and finance, a plan unveiled by Dublin City Council in 2004 had no input from residents or community organisations. This plan was rejected and a period of negotiation was agreed. The council initially resisted having community representatives on the bid assessment panel but relented after a year. The economic crash resulted in this PPP project collapsing in 2008 (Reeves, 2013a).

There appears to have been buy-in to PPP by IBEC, the CIF and, initially, the unions. The trade union experience with the 2006 PAR and the experience in the development of mixed tenure housing indicate that, although Irish PPP may have been supported initially by efforts to gain buy-in from 
constituents, this has been less so in recent years. This is indicative of the increasingly coercive nature of Irish PPP.

(4) Improving public sector knowledge of PPPS

In 1998 an interdepartmental group (IDG) explored the introduction of PPPs with a focus on roads. Farrell Grant Sparks Consultants reported to the IDG in July 1998. This report discussed so-called hiccups in implementing PPPs, as experienced by the UK. Discussions with the UK Treasury Task Force convinced the IDG to create a central PPP unit in 1999, as well as PPP units in the Departments of the Environment, Education and Public Enterprise (Connolly et al., 2009b).

There is evidence of efforts to provide PPP-specific training and guidance to public sector staff. Also it appears the IDG endeavoured to learn from the UK experiences, but it is unclear whether this was effectively communicated to key public sector managers. This view was echoed by the senior economist who noted there had been significant opportunities for learning at specialised conferences with expert participation, which may have helped the ongoing 'learning by doing' processes.

\section{(5) Establishing a PPP unit}

Founded in 2002, the NDFA can be considered partially to fulfil the functions of what can be described as a 'dedicated PPP unit'. In 2012 the UK HM Treasury called for a stronger government role where equity investment would be managed by 'a commercially-focused central unit located in Treasury ... managed by individuals with the appropriate professional skills to oversee the investment and make commercial decisions'. IBEC's call for the establishment of a 'National Infrastructure Authority' with strategic policy responsibility for determining whether PPP is an adequate delivery mechanism indicates similar dissatisfaction with the existing arrangements in Ireland. This is mirrored by trade union calls for crossdepartmental coordination of PPP activity (Irish Congress of Trade Unions, 2011), which 
suggests that while Ireland has an organisation - the NDFA - it does not yet fulfil all the functions it ideally should pursue.

\section{(6) Coordinating deal flow}

At a PPP conference held in Dublin on 21 March 2013, the Minister of State for Public Service Reform and the Office of Public Works announced changes to PPP projects aimed at instilling confidence and maximising market participation. These were: reducing to 15 months the timeframe for preparing PPP projects to the market through to contract award, and reimbursing bid costs to unsuccessful bidders. The Minister also stated the PPP process would be streamlined, with less documentation and meetings and specimen designs drawn up prior to the bidding process. This was confirmed by the senior economist who highlighted current measures to reduce the historically lengthy negotiation process which could require periods of two years and more for contract completion.

There are similarities between the announcements in Ireland and the UK PF2 reform measures introduced by HM Treasury in December 2012. The UK reforms reduced the tendering phase of PF2, allowed the government to subsidise bid costs, and reduced the amount of design work to be carried out for bids (HM Treasury, 2012). Similarly the UK expected the pipeline of PFI deals to stimulate national and local economies (National Audit Office, 2010), while Ireland's domestic infrastructure stimulus package of July 2012 envisioned $€ 1.4$ billion to be delivered through PPP. vi

Both Ireland and the UK have taken measures to increase the PPP deal flow post the 2008 crisis. This highlights the vulnerability of the PPP industry to economic shocks and indicates that neither Ireland nor the UK had a structured national infrastructure policy. The senior economist noted it was difficult initially to attract international companies and create sufficient market interest for scalability reasons but the government was addressing this issue by creating a pipeline of PPP projects. The similarities of policy responses indicate the lasting legacy of policy transfer between the two countries. 


\section{(7) Improving programme transparency}

Policies aimed at improving the transparency of the PPP process in Ireland have been rife with contradictions. A 2012 Comptroller and Auditor General (C\&AG) report recommended that 'evaluations of the value for money expected to be achieved through procurement of projects by means of PPP should be published' and stated '... a PPP cannot proceed unless it is found likely to deliver better value than traditional procurement' yet 'few value for money reviews of PPP projects have been published'. vii The report noted that the NDFA had carried out value for money testing on the third schools bundle project, but the results of the final deal had not been disclosed as they could compromise negotiations.

The Chief Executive of the National Roads Authority(NRA) reported to the Committee of Public Accounts in 2013 that he could not 'reveal the individual consortia's precise commercially sensitive information' on the M3 PPP motorway project. When discussing PPPs carried out by the Department of Education, the Secretary General of the Department regarded requests for disclosure that 'we will have to make the call in terms of commercial sensitivity. . the public sector benchmark decision certainly is commercially sensitive for a number of years.'

There have been few value for money reviews of PPPs in Ireland yet other jurisdictions make such information available. The government of Victoria (Australia) provides disclosure on all PPP contracts (English et al., 2004). It is not surprising that IBEC has called for greater transparency around the planning process (IBEC, 2013).

There is a strong indication that although value for money assessments are given central importance by the Irish government, full evaluation is not taking place. The senior member of the public accounts committee stated 'the Department of Public Expenditure and Reform should mandate how to measure value for money.' Similarly, the senior trade union informant said 'there is no empirical evidence in the public domain that a PPP is better value for money.' As evaluations of these assessments are not in the public domain because of commercial sensitivity issues, neither Ireland nor the UK fully meets this requirement for sustainability. 
(8) Ensuring the quality of projects

The decision to implement PPPs in Ireland followed the publication of the 1998 Farrell Grant Sparks report which listed the benefits as a focus on service outcomes rather than the assets, optimum risk allocation, and value for money. These expectations were not fully confirmed by later reports. A 2004 C\&AG value for money report on the Grouped Schools Pilot Partnership Project initially commented positively on this first PPP pilot project. It noted that 'the cost comparison exercise ... concluded that procuring and running the schools through the proposed PPP arrangement would result in a saving of around 6\% compared to procuring and running the schools conventionally.' However, in light of the recognition that 'the analysis contained errors in relation to the timing and discounting of payments and overestimated the residual value of the school buildings at the end of 25 years'viii, subsequent analysis suggested that PPP was between $13 \%$ and $19 \%$ more expensive than conventional procurement, with relatively little risk transfer to the private sector. The C\&AG concluded that it was too early for a comprehensive comparison of the economy, efficiency and effectiveness of the school PPPs.

Reeves (2013a) writes that the Department of the Environment preferred PPP in the water services sector. Although the Department initially estimated the whole-life costs of a replacement wastewater treatment plant to be $2.3 \%$ lower under traditional procurement, a re-worked estimate indentified a differential of less than $1 \%$ in favour of traditional procurement. Nonetheless, the Department decided to proceed with PPP procurement (Reeves, 2013a). Despite problems, there is evidence of some success, as exemplified by a post-project review of the Criminal Courts of Justice PPP where a 2008 C\&AG report verified 6\% lower costs for the PPP (IBEC, 2011).

On risk transfer and the quality of PPP projects in Ireland, the senior economist noted that, the small population of the country meant road projects in particular continued to suffer from poor estimates of demand risk, with the government frequently accepting 'all of the downside risks' without 'benefiting from potential upside risks'. The literature supports this when discussing the implementation of a dedicated formal risk framework not guaranteeing effective patterns of risk 
assessment and management (Asenova et al., 2007). There is mixed evidence of value for money and risk transfer being achieved, with some projects performing within or above expectations and others being problematic.

(9) Implementing independent oversight of project development and execution

Regulatory oversight of Irish PPPs is problematic. Responsibility for water services and water/wastewater PPPs transferred to the state-owned utility Irish Water in 2014. The C\&AG does not audit the accounts of commercial state companies and subsidiaries. The Commission for Energy Regulation has responsibility for regulating water and reviewing Irish Water's underlying costs of provision of water and wastewater services. ${ }^{i x}$ Whether this will involve the publication of information on PPPs is unclear.

As statutory financial adviser the NDFA has responsibility for the procurement of PPPs in sectors other than transport, local authorities and the direct procurement of certain education projects. ${ }^{\times}$It performs its functions through the National Treasury Management Agency, and, while its fees and expenses are audited by the C\&AG, the auditor does not oversee procurement decisions nor publish performance monitoring results of the NDFA.

This suggests a high degree of fragmentation in the regulatory oversight of Irish PPP. While this would be unproblematic if each agency carried out its assessment to similar standards, current practice is likely to make performance comparisons of PPP across different areas of activity difficult.

\section{Conclusions}

The core objective of this analysis has been to identify the impact of adoption patterns on the sustainability of PPP in post-crisis Ireland. Combining policy transfer and institutional theory, four possible adoption patterns were identified:

- voluntary policy transfer with strong institutional capacity building;

- coercive policy transfer and strong institutional capacity building; 
- voluntary policy transfer and weak institutional capacity building; and

- coercive policy transfer and weak institutional capacity building.

Our preliminary empirics suggest that policy transfer was initially largely voluntary, although specific elements of implementation, such as limits on transparency on account of commercial sensitivity, were perceived as coercive by our informants. This coercive element was largely attributed to industry expectations which had developed within the UK PFI market. For the pre-crisis period, government announcements seem to indicate that PPP was seen as a means of catching up with 'modern procurement methods' as practised in other English-speaking countries such as the UK where ministers were keen to introduce what they saw as 'innovative, entrepreneurial business values' into public services (Weaver, 2003). Unsurprisingly, Ireland's 2003 PPP policy framework closely mirrored the earlier UK Green Book. Government documents written and exploratory interviews conducted post-crisis suggest that PPP has ceased to be a voluntary option, being instead perceived as an economic necessity. This seems to have given rise to the accelerated development of a supportive legal framework and enabling measures.

Regarding the nine factors examined - supportive legal framework, political commitment, buy-in from key constituents, good public sector knowledge of PPPs, a PPP unit, measures to coordinate deal flow, program transparency and ensuring the quality of projects while implementing independent oversight - we note that not all these factors have been accomplished. We find evidence of the development of a supportive and comprehensive legal framework that is widely utilised as well as strong political commitment by government. This also applies to improvements in public sector PPP skills which benefited from the establishment of the Central PPP Policy Unit in 1999 and the creation of the NDFA.

More mixed results can be observed in the efforts to gain buy-in from key constituents. Buyin seems to have been fairly broad in the early stages, with support being articulated by the employers' association, industry bodies and trade unions. By the mid to late 2000s this had partially eroded, with trade unions and community groups voicing concerns over inadequate consultation. 
Another problem is the coordination of deal flow. Both Ireland and the UK suffered from delays in contract awards and financial closure, haphazard bidding processes (resulting in high costs and losses to bidders) and uneven demand. Efforts were made to address this in Ireland in 2013, with measures aimed at instilling confidence and maximising market participation in PPP following the UK's PF2 reform package.

The lack of frameworks for ensuring PPP quality appears to be the most significant institutional barrier to the sustainability of Irish PPP. This concerns objective and systematic value for money evaluations of existing and future deals, which are hampered by fragmentation and a lack of detailed cost and return data which allegedly arises from the commercial confidentiality needs of private participants. Uncertainty about risk allocation between partners and the costing of risk transfer seems to affect adversely the accuracy and reliability of value for money calculation. The Clonee-Kells (M3) and Limerick tunnel PPPs have suffered shortfalls in traffic volumes resulting in the NRA making guaranteed payments to the PPP companies. ${ }^{\text {xi }}$ This is a serious issue as government organisations put great emphasis on these assessments.

Major difficulties in the sustainability of Irish PPPs also arise from lack of transparency and poor oversight. Government documents and interview informants highlight problems in obtaining financial data on operating costs and profits which would allow for a thorough assessment of existing and future projects. This could have serious repercussions because learning about the performance of PPP projects is obstructed. This is compounded by a lack of effective independent oversight, which arises from the fragmentation of regulatory control. The institutional framework is not fully developed and there is need for improvement.

PPP is not the 'only game in town' and from a practitioner point of view its adoption should be voluntary. Alternatives should be examined for each project and underpinned by rational decisionmaking. If such decision-making is not employed, and value for money testing is not robust, there is a danger of PPP becoming a long-term threat to public finances. PPP is complex and relies on networks and partnering, which may be difficult in a small country such as Ireland. This creates unique 
challenges in terms of managing processes and ensuring accountability (Willems et al., 2011). This cannot be addressed through specific legal/regulatory measures alone but requires a broad institutional response in terms of building institutional capacity (Jooste et al., 2009). For Ireland to create a strong, sustainable framework for PPP implementation requires the creation of credible and transparent accountability frameworks linked to a broader vision about the future of the nation's infrastructure and the desirable characteristics of procurer provider relationships. 
Notes:

${ }^{1}$ http://www.per.gov.ie/en/building-on-recovery-infrastructure-and-capital-investment-2016-2021statement-of-the-minister-for-public-expenditure-and-reform-mr-brendan-howlin-t-d-on-29september-2015/

${ }^{1}$ www.ppp.gov.ie

${ }^{1}$ The remaining measures which will form part of our extended study they are: increasing public awareness and understanding of PPPs; developing a market of private providers; providing government support for private providers; keeping line agency discretion in check; monitoring behaviour of private providers; increasing program accountability; ensuring management support to public sector agencies on specific projects; ensuring PPP projects promote the public interest; ensuring fairness of PPP procurement; and improving environmental performance of projects.

i http://www.per.gov.ie/en/building-on-recovery-infrastructure-and-capital-investment-2016-2021statement-of-the-minister-for-public-expenditure-and-reform-mr-brendan-howlin-t-d-on-29september-2015/

ii www.ppp.gov.ie

iii The remaining measures to be utilised at a later stage are: increasing public awareness/ understanding of PPPs; developing a market of private providers; providing government support for private providers; keeping line agency discretion in check; monitoring behaviour of private providers; increasing program accountability; ensuring management support to public sector agencies on projects; ensuring PPPs promote the public interest; ensuring fairness of procurement; improving environmental performance.

iv http://per.gov.ie/2012/07/17/minister-howlin-announces-an-additional-e2-25-billion-domesticinfrastructure-stimulus-to-create-much-needed-jobs/

$\checkmark$ Public Private Partnership - Stakeholder Consultation for Employees and their Representatives, January 2005.

visee note i 
vii C\&AG Report on the Accounts of the Public Services 2011 (September 2012), chapter 6, paragraph 6.30 and 6.50 .

viii C\&AG Report on Value for Money Examination 48, The Grouped Schools Pilot Partnership Project, June 2004, page 11.

${ }^{\text {ix }}$ www.CER.ie/water/

${ }^{\times}$C\&AG Report on the Accounts of the Public Services 2013 (September 2014), paragraph 17.29.

${ }^{x i}$ C\&AG Report on the Accounts of the Public Services 2011 (September 2012), paragraph 6.20

Table 1: Factors affecting the sustainability of PPP policy transfer

\begin{tabular}{|c|c|c|c|}
\hline \multirow{4}{*}{$\begin{array}{c}\text { Degree of } \\
\text { Institutional } \\
\text { Capacity Building }\end{array}$} & & Weak & Strong \\
\hline & Voluntary & $\begin{array}{l}\text { (1) Voluntary PT \& } \\
\text { weak institutional } \\
\text { capacity building }\end{array}$ & $\begin{array}{l}\text { (2) Voluntary PT \& } \\
\text { strong institutional } \\
\text { capacity building }\end{array}$ \\
\hline & Coercive & $\begin{array}{l}\text { (3) Coercive PT \& } \\
\text { weak institutional } \\
\text { capacity building }\end{array}$ & $\begin{array}{l}\text { (4) Coercive PT \& } \\
\text { strong institutional } \\
\text { capacity building }\end{array}$ \\
\hline & & \multicolumn{2}{|c|}{ Degree of Policy Transfer } \\
\hline
\end{tabular}




\section{References}

Abdel Aziz, AM (2007) Successful delivery of public-private partnerships for infrastructure development. Journal of Construction Engineering and Management 133(12): 918-931.

Akintoye, A., Hardcastle, C. and Beck, M. (eds) (2003) Public-Private Partnerships: Managing Risks and Opportunities. Oxford: Blackwell.

Asenova, D., Stein, W., McCann, C. and Marshall, A. (2007) 'Private Sector Participation in Health and Social Care Services in Scotland', International Review of Administrative Sciences 73(2): 275-292.

Brignall, S. and Modell, S. (2000) An Institutional Perspective on Performance Measurement and Management in the 'New Public Sector'. Management Accounting Research 11(3): 281-306.

Broadbent, J. and Laughlin, R. (2004) 'PPPs: Nature, Development and Unanswered Questions', Australian Accounting Review 14(3): 4-10.

Broadbent, J. and Laughlin, R. (2005) 'The Role of PFI in the UK Government's Modernisation Agenda', Financial Accountability \& Management 21(1): 75-97.

Budina, N., Brixi, H.P. and Irwin, T. (2007) Public-Private Partnerships in the New EU Member States. Washington DC: World Bank.

Connolly, C., Reeves, E., and Wall, A. (2009a) 'Isomorphism: An explanation for the popularity of Public-Private Partnerships', Irish Accounting Review 16(1): 1-19.

Connolly, C., and Wall, T. (2009b) Public Private Partnerships in Ireland: Benefits, Problems and Critical Success Factors. Dublin: The Institute of Chartered Accountants in Ireland.

Corbacho, M.A., Funke, K. and Schwartz, M.G. (eds) (2008) Public Investment and Public-Private Partnerships. Washington DC: International Monetary Fund.

Department of the Environment, Heritage and Local Government (2003) Policy Framework for Public Private Partnership (PPP) in Ireland. Dublin: DoHELG.

Department of the Taoiseach (2000) Programme for Prosperity and Fairness. Dublin: Taoiseach.

Dimaggio, P.J. and Powell, W.W. (1983) 'The Iron Cage Revisited', American Sociological Review 48(2): 147-160.

Dolowitz, D. and Marsh, D. (1996) 'Who Learns What from Whom', Political Studies 44(2): 343-357.

Dolowitz, D. and Marsh, D' (2000) 'Learning from Abroad', Governance 13(1): 5-23.

English, L. and Walker, R.G. (2004) 'Risk Weighting and Accounting Choices in Public-Private Partnerships', Australian Accounting Review 14(2): 62-76.

Evans, M. (2009) 'Policy Transfer in Critical Perspective', Policy Studies 30(3): 243-268. 
Farrell Grant Sparks and Goodbody Economic Consultants, with Chesterton Consulting (1998). Report to the Inter-Departmental Group in Relation to Public Private Partnerships. Dublin: FGS\&GEC.

Hearne, R. (2009) Origins, Development and Outcomes of Public Private Partnerships in Ireland. Dublin: Combat Poverty Agency.

HM Treasury (2003) The Green Book Appraisal and Evaluation in Central Government. London: TSO.

HM Treasury (2012) A New Approach to Public Private Partnerships. London: TSO.

Hodge, G.A. (2004) 'The Risky Business of Public-Private Partnerships', Australian Journal of Public Administration, 29(1): 33-39.

Hodge, G.A. and Greve, C. (2007) 'Public Private Partnerships', Public Administration Review 67(3):545-558.

Hodge, G.A. and Greve, C. (2009) 'Public Private Partnerships', Economic Affairs 29(1):33-39.

Hodge, G.A. and Greve, C. (2010) 'Public-Private Partnerships', Australian Journal of Public Administration 69(1): S8-S22.

Hodge, G.A. and Greve, C. (2011) 'Theorizing Public-Private Success', Public Management Research Conference, Syracuse University 2-4 June..

Irish Business and Employers' Confederation (2013) Infrastructure 2020: Building Beyond the Bailout. Dublin: IBEC.

Irish Business and Employers' Confederation (2011) What Next for Infrastructure? Dublin: IBEC.

Irish Congress of Trade Unions (2011) State Companies and the Threat of Privatisation. Dublin: ICTU.

Jooste, S.F., Levitt, R.E. and Scott, W.R. (2009) Capacity, Legitimacy, and Interest: Toward a framework for PPP Program Success. Paper for the Lead 2009 Conference, South Lake Tahoe CA.

Jooste, S.F., Levitt, R.E. and Scott D. (2011) 'Beyond "One Size Fits All"', The Engineering Project Organization Journal 1(1): 11-25.

Leinhard, A. (2006) 'Public Private Partnerships (PPP) in Switzerland', International Review of Administrative Sciences 72(4): 547-563.

Marsh, D. and Sharman, J.C. (2009) 'Policy Diffusion and Policy Transfer', Policy Studies 30(3): 269288.

Massey, A. (2010) 'Lessons from Africa: New Public Management and the Privatization of Kenya Airways', Public Policy and Administration 25(2): 194-215.

Matos-Castaño, J., Mahalingam, A. and Dewulf, G. (2014) 'Unpacking the Path-Dependent process of Institutional Change for PPPs', Australian Journal of Public Administration 73(1): 47-66.

National Audit Office (2010) Financing PFI Projects in the Credit Crisis. London: TSO. 
National Development Finance Agency (2013) Have Ireland's PPPs Come Back to Life?', Dublin: NDFA February.

National Economic and Social Council (1999) Opportunities, Challenges and Capacities for Choice. Dublin: NESC.

Newberry, S. (2004) 'Trade in Services: Wider Implications for Accounting Standard-Setters and Accountants,' Australian Accounting Review 14(33): 11-21.

Northoff, T. (2008) 'Public Private Partnerships', Presentation to UNECE, New York, 28 February.

Public Private Partnership Advisory Group (2001) Framework for Public Private Partnerships. Dublin: PPPAG.

Radaelli, C.M. (2000) 'Policy Transfer in the European Union', Governance 13(1): 25-43.

Reeves, E. (2003) 'Public-private partnerships in Ireland', Public Money \& Management 23(3): 163170.

Reeves, E. (2013a) 'The Not so Good, the Bad and the Ugly', Local Government Studies 39(3): 375-395.

Reeves, E. (2013b) 'Public-Private Partnerships in Ireland', Department of Economics Papers, University of Limerick, Limerick.

Sheppard, G. (2016) 'Public Private Partnerships in the Republic of Ireland', in Akintola Akintoye, Matthias Beck, and Mohan Kumaraswamy (eds) (2003) Public-Private Partnerships-A Global Review. London: Routledge.

Teicher, J., Alam, Q., and Van Grambers, B. (2006) 'Managing Trust and Relationships in PPPs', International Review of Administrative Sciences 72(1): 85-100.

Verhoest, K., Carbonara, N., Lember, V., Petersen, O.H., Scherrer, W. and Van den Hurk, M. (2013) Public Private Partnerships in Transport. Cost Action TU1001 i-xxV.

Weaver M (2003)'PFI', The Guardian UK Society, 15 January.

Willems, T. and Van Dooren, W. (2011) Lost in Diffusion? How Collaborative Arrangements Lead to an Accountability Paradox, International Review of Administrative Sciences 77(3): 505-530. 